\title{
Systematic lymph node sampling at operation results in more node positive staging in NSCLC
}

\author{
J Whiteley", G Beattie, A McKay, A Kirk, M Asif \\ From World Society of Cardiothoracic Surgeons 25th Anniversary Congress, Edinburgh \\ Edinburgh, UK. 19-22 September 2015
}

\section{Background/Introduction}

It has been shown that the survival of patients with NSCLC is related to nodal involvement. Both BTS and SIGN guidelines recognise that simple nodal sampling is not adequate to accurately stage NSCLC and recommend at least systematic sampling of mediastinal nodes. In the West of Scotland all patients with node positive disease are considered for adjuvant chemotherapy. This requires accurate staging of lymph nodes.

\section{Aims/Objectives}

We report on the nodal staging of all patients in 2012 and 2013 who underwent lung resection.

\section{Method}

All patients who underwent surgery for NSCLC at The Golden Jubilee National Hospital in 2012 and 2013 were included. Data were collected on histological diagnosis, $\mathrm{T}$ and $\mathrm{N}$ staging from histology reports, the lymph nodes stations sampled at operation and the operating surgeon. Adequate lymph node sampling was considered to have been performed if more than three mediastinal lymph node stations were sampled, as this is a quality performance indicator set out by NHS Scotland.

\section{Results}

583 patients underwent lung resection. There was no difference in the proportion of patients with nodal disease between operating consultant $(\mathrm{p}=0.120)$. In this cohort, as the number of lymph node stations sampled increased, the proportion of node positive disease increased from $16 \%$ and $19 \%$ if only 1 or 2 lymph node stations were sampled respectively, to $42 \%$ node positive if more than 6 stations were sampled $(\mathrm{p}=0.002)$. When 3 or more mediastinal lymph node stations were

Golden Jubilee National Hospital, Clydebank, Dunbartonshire G81 4DY, UK sampled, then the detection of nodal disease increased by $50 \%(\mathrm{p}=0.006)$.

\section{Discussion/Conclusion}

By sampling more mediastinal lymph nodes, more diseased lymph nodes were detected. This meant these patients were more accurately staged and considered for adjuvant chemotherapy, therefore potentially increasing their chances of survival.

Published: 16 December 2015

doi:10.1186/1749-8090-10-S1-A346

Cite this article as: Whiteley et al: Systematic lymph node sampling at operation results in more node positive staging in NSCLC. Journal of Cardiothoracic Surgery 2015 10(Suppl 1):A346.
Submit your next manuscript to BioMed Central and take full advantage of:

- Convenient online submission

- Thorough peer review

- No space constraints or color figure charges

- Immediate publication on acceptance

- Inclusion in PubMed, CAS, Scopus and Google Scholar

- Research which is freely available for redistribution
() Biomed Central 